\title{
Pollen records of the 14th and 20th centuries AD from Lake Tsizavatsy in southwest Madagascar
}

\author{
Estelle Razanatsoa \& Lindsey Gillson \\ Plant Conservation Unit, Department of Biological Sciences, University of \\ Cape Town, South Africa \\ Malika Virah-Sawmy \\ Humboldt-Universität, Geography, Berlin, Germany
}

Stephan Woodborne

iThemba LABS, Johannesburg, South Africa

\subsection{SITE DETAILS}

Lake Tsizavatsy is located at the north of the Mangoky River, in the southwest of Madagascar $\left(21.780^{\circ} \mathrm{S}, 43.897^{\circ} \mathrm{E}\right.$, at $45 \mathrm{~m}$ asl, Figure 1$)$. The region has an extensive formation of sandstone eroded from the Precambrian basement and also less eroded tertiary limestones of marls and chalks from marine facies formed during the Eocene (Du Puy and Moat 1996; Moat and Smith 2007) that occur near the coast between 0 and $300 \mathrm{~m}$ asl. The region's climate is characterised by semi-arid conditions with pronounced seasonality (Donque 1972) and annual precipitation ranging from $400-600 \mathrm{~mm}$ per year near the coast (Stiles 1998). The site's vegetation is classified as tropical dry forests with patches of savanna and woodland savanna and some agricultural areas (Figure 1). These savannas include a small number of tree species belonging to the Arecaceae family that are highly adapted to fire, such as cf. Medemia nobilis (Grubb 2003). In addition, there is a patchy sclerophyllous forest which contains taxa such as Leptolaena spp. and a high number of dry adapted species such as those belonging to the Euphorbiaceae and Didiereaceae families (Moat and Smith 2007). Lake Tsizavatsy is a shallow lake of approximately $500 \mathrm{~m}$ in diameter. The local community reports that the lake recedes to half its area during the dry season. The lake did not exceed a depth of $0.5 \mathrm{~m}$ during our field work in September 2015. The studied sediment core provides a record of at least $10 \mathrm{~km}^{2}$ surrounding the lake representing local to landscape scale of vegetation change. The lake is surrounded by Cyperaceae at the margins and is encompassed by wooded savanna with the presence of degraded and intact dry forest in the wider landscape. Within and around the lake, taxa such as Phragmites mauritianum (Poaceae), Cryptostegia madagascariensi (Apocynaceae), Acacia morondavensis (Fabaceae), Hyphaene shatan (Arecaceae), and Euphorbia spp. (Euphorbiaceae) are found. The communities surrounding this area comprise foragers and maize horticulturalists (Mikea), agropastoralists (Masikoro), and fishers (Vezo). 


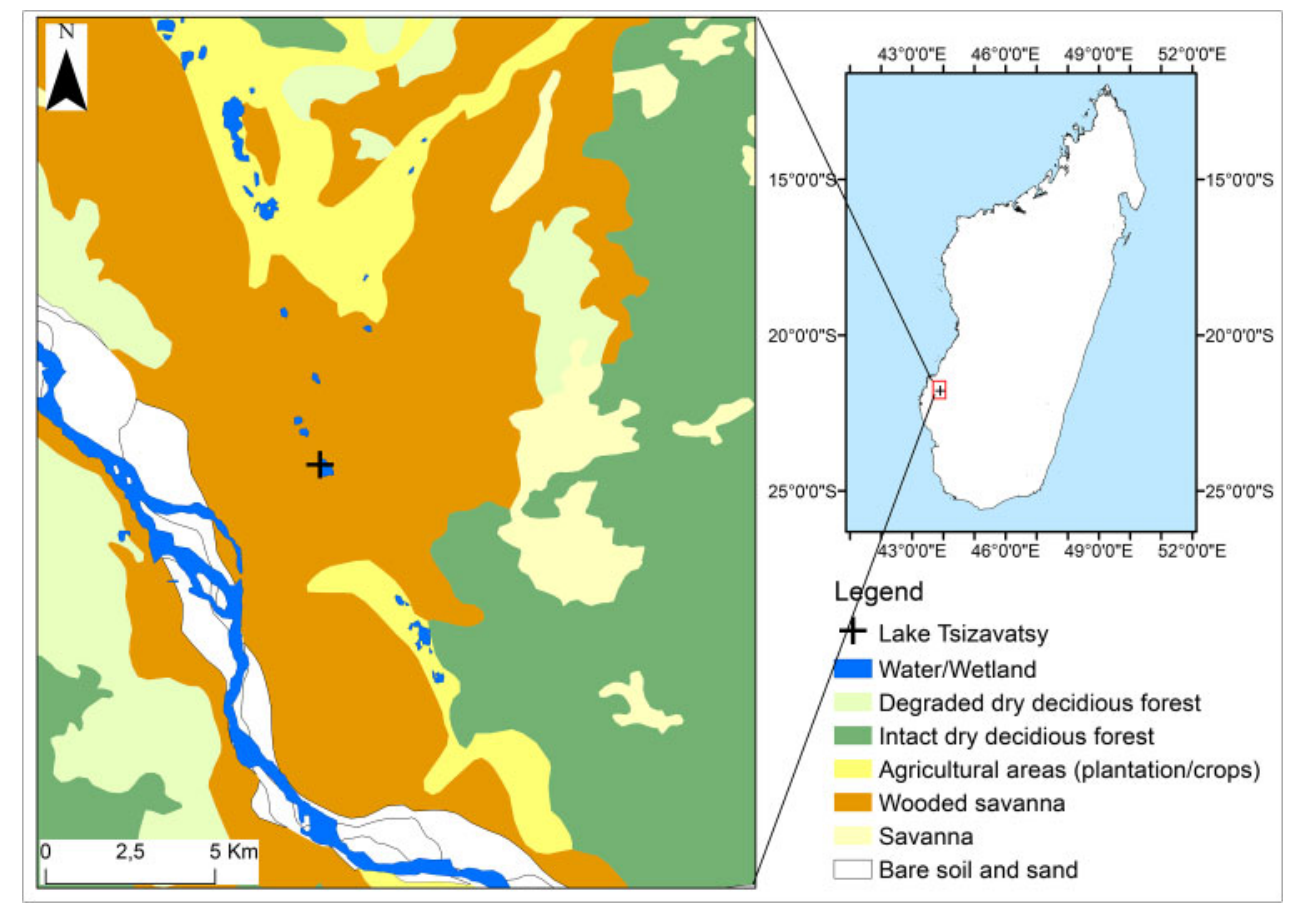

Figure 1. Location of the study site in southwest Madagascar. The red box (black cross) indicates Lake Tsizavatsy. Source: Moat and Smith (2007).

\subsection{SEDIMENT DESCRIPTION AND METHODS}

A $48 \mathrm{~cm}$ sediment core was obtained from the edge of Lake Tsizavatsy using a Russian corer in August 2015. Lithostratigraphic units were described using a modified version of the TroelsSmith classification (Kershaw 1997; Table 1). Twelve sub-samples of $1 \mathrm{~cm}^{3}$ were taken from the core for pollen extraction following Bennett and Willis (2001). Pollen was counted using a Leica microscope DM750 and identification was based on published pollen references (Gosling et al. 2013; Vincens et al. 2007). A pollen sum of at least 250 terrestrial taxa was achieved for each sample and relative abundances were calculated and plotted using C2 Version 1.7.7. (Juggins 2003). Cluster analysis was performed using the CONISS method (Analogue package) in R (Grimm 1987; R core Team 2018) to identify zones related to temporal change of the vegetation. Diversity was measured through rarefaction analysis and beta diversity (Birks and Line 1992).

\subsection{DATING}

Four AMS radiocarbon dates were obtained from sub-samples (4-10 g) of bulk sediment extracted from the Lake Tsizavatsy core (Table 2). Measurements were made at the iThemba LABS facility in Johannesburg (South Africa), Beta analytic Inc, Laboratory in Florida (USA), and 14-CHRONO labs in Belfast (UK) (Table 2). Dates were calibrated using the southern hemisphere calibration curve (Hogg et al. 2020) and the age-depth model plotted based on the linear interpolations of age point estimates for depths on weighted means of the dated levels. 
Table 1. Lithostratigraphic units of the sediment core from Lake Tsizavatsy.

\begin{tabular}{|c|c|c|c|c|c|}
\hline $\begin{array}{l}\text { Depth } \\
(\mathrm{cm})\end{array}$ & Unit & $\begin{array}{l}\text { Troels- } \\
\text { Smith }\end{array}$ & Description & $\begin{array}{l}\text { Munsel } \\
\text { colour } \\
\text { code }\end{array}$ & Colour \\
\hline $16-0$ & $\begin{array}{l}\text { TSZ- } \\
\text { strat } 3\end{array}$ & As3 Ld1 & $\begin{array}{l}\text { Clayey and not very } \\
\text { humified deposits }\end{array}$ & $\begin{array}{l}2.5 \mathrm{Y} 3 / / 1 \\
\text { or } 5 \mathrm{Y} 3 / / 1\end{array}$ & $\begin{array}{l}\text { Very dark } \\
\text { grey }\end{array}$ \\
\hline $28-17$ & $\begin{array}{l}\text { TSZ- } \\
\text { strat } 2\end{array}$ & $\begin{array}{l}\text { As2 Ga1 } \\
\text { Ld1 }\end{array}$ & $\begin{array}{l}\text { Clayey and fine sand } \\
\text { deposits, few organic } \\
\text { materials }\end{array}$ & 10YR 4//4 & $\begin{array}{l}\text { dark } \\
\text { yellowish } \\
\text { brown }\end{array}$ \\
\hline $48-29$ & $\begin{array}{l}\text { TSZ- } \\
\text { strat } 1\end{array}$ & $\begin{array}{l}\text { As2 Ge1 } \\
\text { Ld1 }\end{array}$ & $\begin{array}{l}\text { Clayey and coarse sand } \\
\text { deposits, low humicity } \\
\text { deposits }\end{array}$ & $5 Y 3 / / 2$ & $\begin{array}{l}\text { Dark olive } \\
\text { grey }\end{array}$ \\
\hline
\end{tabular}

Table 2. Radiocarbon age of the Lake Tsizavatsy (TSZ) sediment core. Measurements were conducted at 14-CHRONO Centre Queens University (code AUB), iThemba Labs (IT) and Beta Analytic (Beta) and raw radiocarbon dates were calibrated using the southern hemisphere calibration curve (Hogg et al. 2020). Uncal. = uncalibrated. Cal. = calibrated. Prob. $=$ probability. $\mathrm{BP}=$ before present $(\mathrm{AD} 1950)$.

\begin{tabular}{|c|c|c|c|c|c|c|}
\hline $\begin{array}{l}\text { Depth } \\
(\mathrm{cm})\end{array}$ & Code & $\begin{array}{l}\mathrm{Lab} \\
\mathrm{ID}\end{array}$ & $\begin{array}{l}\text { Uncal. } \\
{ }^{14} \mathrm{C} \text { dates }\end{array}$ & $\begin{array}{l}\delta^{13} \mathrm{C} \\
\% 0\end{array}$ & $\begin{array}{l}\text { Calibrated } \\
\text { ages }\end{array}$ & $\begin{array}{l}\text { Prob. } \\
(\%)\end{array}$ \\
\hline $24-25$ & $\begin{array}{c}\text { TSZ } \\
24\end{array}$ & $\begin{array}{l}\text { UBA- } \\
35667\end{array}$ & $\begin{array}{c}106 \pm 28 \\
\text { yr BP }\end{array}$ & -18.55 & AD 1804-1935 & 67.4 \\
\hline $29-30$ & $\begin{array}{c}\text { TSZ } \\
29\end{array}$ & $\begin{array}{l}\text { IT-C- } \\
1739\end{array}$ & $\begin{array}{l}640 \pm 62 \\
\text { yr BP }\end{array}$ & -19.8 & $\begin{array}{l}\text { AD } 1378-1406 \\
(572-544 \text { cal. yr BP })\end{array}$ & 68.3 \\
\hline $35-36$ & $\begin{array}{c}\text { TSZ } \\
35\end{array}$ & $\begin{array}{l}\text { IT-C- } \\
1608\end{array}$ & $\begin{array}{l}680 \pm 40 \\
\text { yr BP }\end{array}$ & -20.0 & $\begin{array}{l}\text { AD } 1289-1396 \\
(661-554 \text { cal. yr BP) }\end{array}$ & 94.5 \\
\hline $43-44$ & $\begin{array}{c}\text { TSZ } \\
43\end{array}$ & $\begin{array}{l}\text { Beta- } \\
435564\end{array}$ & $\begin{array}{l}640 \pm 30 \\
\text { yr BP }\end{array}$ & -18.2 & $\begin{array}{l}\text { AD } 1301-1365 \\
(649-585 \text { cal. yr BP })\end{array}$ & 94.4 \\
\hline
\end{tabular}

\subsection{INTERPRETATION}

We identified 65 pollen taxa from 33 families, excluding broken and unidentified grains. The pollen analysis revealed two pollen zones, TSZ_1, and TSZ_2. Radiocarbon dates revealed a hiatus at about $24 \mathrm{~cm}$ dividing the core into two parts covering the 14th and the 20th century (Figure 2). The hiatus is probably caused by sediment scouring from the floodwaters of the Mangoky River during wet periods similar to those recorded for example at the Lake Ihotry in the south of the river (Vallet-Coulomb et al. 2006). The two pollen zone assemblages cover the periods from AD 1300-1420 (48-25 cm, TSZ_1) and AD 1910-2010 (24-0 cm, TSZ_2). We use these data to compare the 14 th century vegetation with that of the 20th century (Figure 3 ).

\subsubsection{Tsizavatsy Zone 1 (TSZ_1): 5 samples, 48-28 cm depth, AD 1300 to 1420 - Palm-Pandanus wooded savanna}

The TSZ_1 zone is characterised as Palm-Pandanus wooded savanna, as indicated by a high abundance of Poaceae, Arcaceae and tree taxa, including Acacia and Pandanus. The abundance 


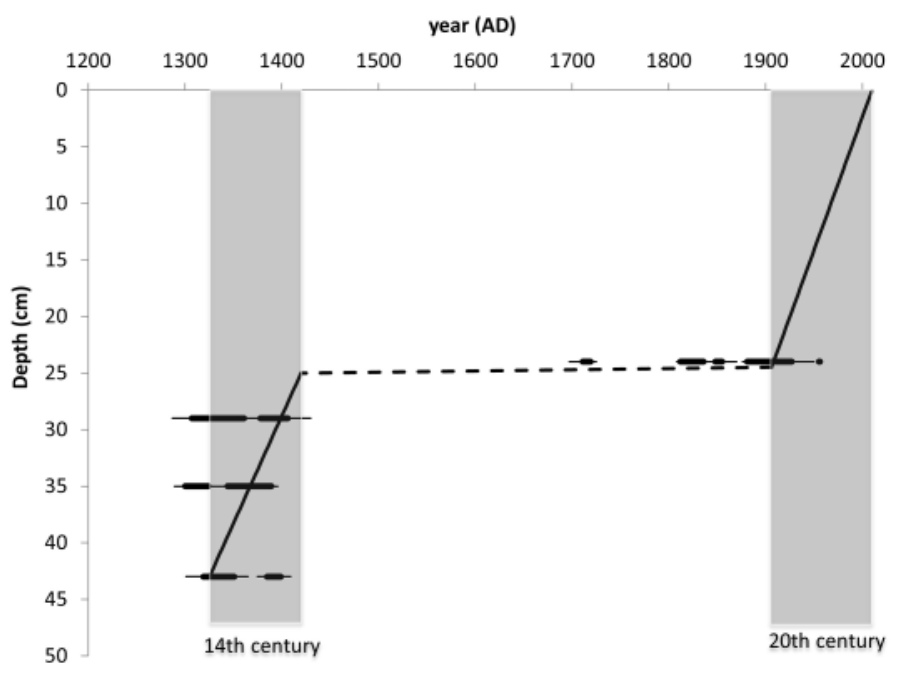

Figure 2. Age depth model of the core from Tsizavatsy adapted from Razanatsoa et al. (in press). Horizontal lines indicate the 1-sigma calibration intervals for the radiocarbon dates done at the depth indicated in the y-axis. Dotted lines indicate the 500-year hiatus period from AD 1420 to 1910.

of Poaceae between AD 1300 and 1420 ranged between $45 \%$ and $71 \%$ (mean c. 60\%), with Arecaceae (c. 5\%) and Acacia (c. 3\%) the most abundant trees. Other notable tree taxa are Pandanus, which reached a maximum of $c .5 \%$ around AD $1330(40 \mathrm{~cm})$ but decreased in relative abundance until around AD $1420(28 \mathrm{~cm})$, while Celtis, Gnidia, and Trema have respective mean values of 3\%, 2\%, and 4\%. All other herbaceous (Asteraceae, Urticaceae and Amaranthaceae type 1) and arboreal (Phyllanthaceae, Myrtaceae, Malvaceae and Moraceae) taxa were present at low abundances in Zone TSZ_1; while aquatic taxa, mostly Cyperaceae, are equivalent to $c$. 10\% of the pollen sum.

\subsubsection{Tsizavatsy Zone 2 (TSZ_2): 7 samples, 24-0 cm depth, AD 1910 to 2010 - Palm-xerophytic degraded wooded savanna}

The TSZ_2 zone is characterised as Palm-xerophytic degraded wooded savanna, marked by the gradual increase in the abundance of xerophytic, herbaceous, and tree taxa, despite the high abundance of Poaceae. Poaceae pollen is highly variable with a minimum value of $45 \%$ at AD $1940(16 \mathrm{~cm})$, and a maximum value of $71 \%$ around AD $2000(2 \mathrm{~cm}$, mean 58\%). The most abundant herbaceous taxon is Asteraceae (mean 4\%) which reaches its highest value around AD 2010 (c. 10\%). All other herbaceous taxa have relatively low abundances. The minimum value of Arecaceae was recorded around AD 2000 (2\%) while the maximum value was recorded at $\mathrm{AD} 1940(16 \mathrm{~cm}, c .12 \%)$. Some taxa, such as Celtis and Gnidia also increased in abundance during this period with a mean value respectively of $c .3 \%$ and $c .2 \%$. Dry adapted taxa such as Securinega (mean c. $2 \%$ ), peak in this zone with a maximum value recorded at AD 1990 (4 cm, 7\%). The aquatic taxa had a mean abundance of c. 10\%; with Myriophyllum (mean c. 1\%), Colocasia (mean c. 2\%) and Cyperaceae (mean c. 6\%) being important components. 


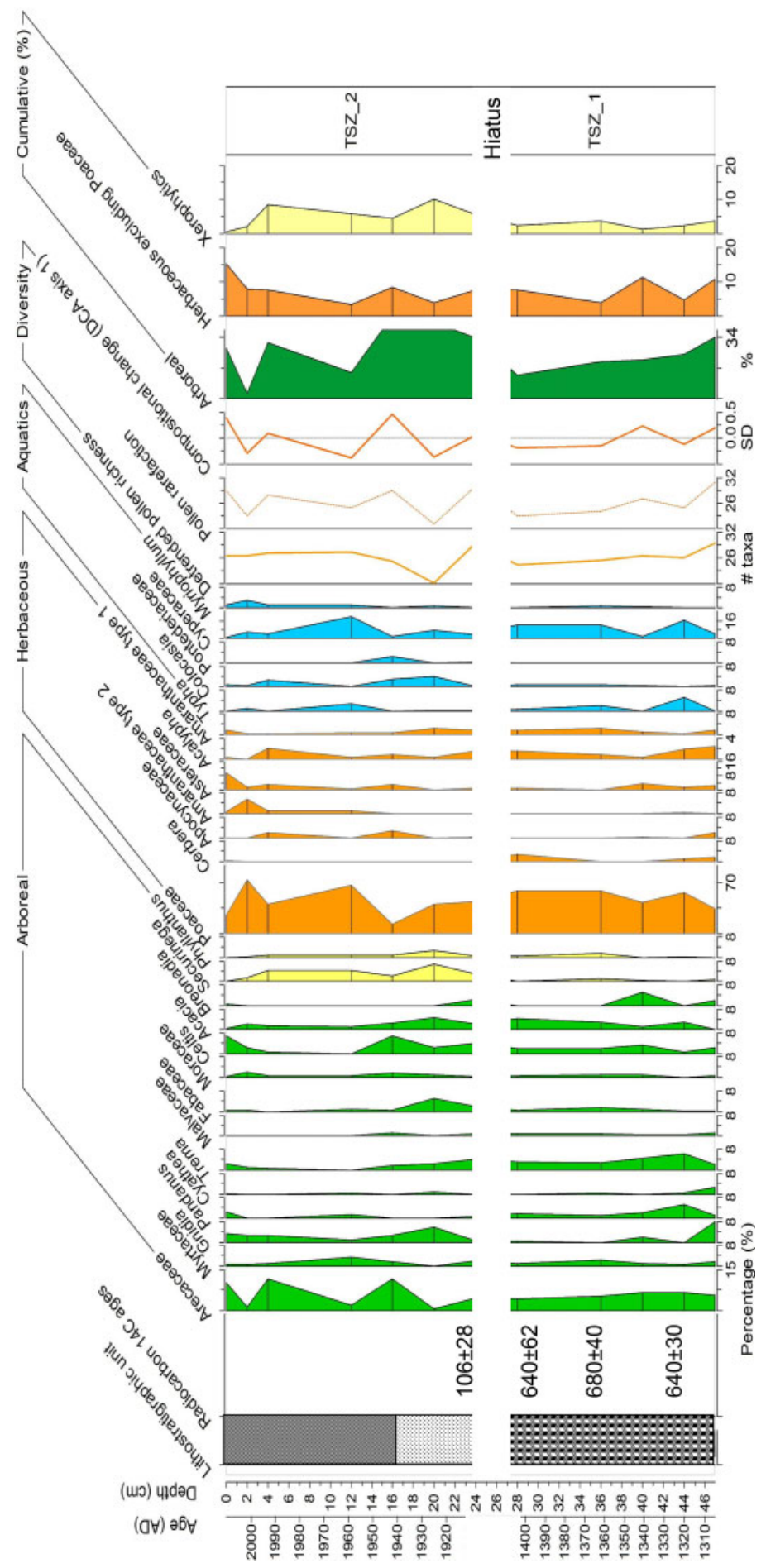

Figure 3. Lake Tsizavatsy summary pollen diagram, showing only taxa with relative abundance $>2 \%$ of the terrestrial pollen sum. Colours indicate taxonomic groupings: green $=$ arboreal taxa, yellow $=$ xerophytic taxa, orange $=$ herbaceous taxa, and blue = aquatic taxa. 


\subsection{COMPARISON OF THE COMPOSITIONAL TURNOVER OF THE VEGETATION DURING THE 14TH AND 20TH CENTURY}

During the two periods, compositional change was recorded around AD 1360 (36cm, $2.65 \mathrm{SD})$, AD 1920 (22 cm, 2.6 SD). During the 14th century, taxa such as Pandanus and Trema were abundant at the beginning but decrease throughout the period which explains the massive turnover around AD $1360(36 \mathrm{~cm})$. The turnover recorded around AD $1920(22 \mathrm{~cm})$ is linked to the increasing dominance of pioneer and xerophytic taxa between AD 1910 to 1940 (24-16 cm). These include Asteraceae, Gnidia, and Securinega in the 20th-century record compared to the 14th century. Overall, the data show a high rate of grass and palm in the surrounding of the lake during both periods. The main difference in the 14th and 20th century pollen records is a slight increase and more variable abundance of arboreal taxa during the latter. An increase in the abundance of xerophytics taxa, possibly linked to decreasing rainfall, was also recorded during the 20th century. Similarly, although tree abundance was higher in the 20th century compared with the 14th century, it began to decrease from the middle of the 20th century. This reduction in trees was associated with a rise in pioneer taxa such as Asteraceae. The pollen data suggest a combined effect of ecosystem degradation and increasing climate impact on the vegetation which requires further investigation.

\section{ACKNOWLEDGEMENT}

We would like to thank the editor and the reviewers for providing helpful feedback to improve the manuscript. We would also like to thank the team in Madagascar that helped with the field work and Tsilavo Razafimanantsoa for helping with the map. This project has been funded as part of the Faculty PhD fellowship (University of Cape Town, R.E.) 2015-2018 and the Applied Centre for Climate and Earth Systems Science (ACCESS NRF UID 98018, R.E.) project, the UCT University Research Committee accredited (URC) from the University of Cape Town [URC, 2019-2020] and SASSCAL (Southern African Science Service Centre for Climate Change and Adaptive Land Management) [466418 c/c BIO1056, 2020].

\section{REFERENCES}

Bennett, K.D., and Willis, K.J., 2001, Pollen. In Tracking Environmental Change Using Lake Sediments Volume 3: Terrestrial, Algal and Siliceous Indicators, edited by Smol, J.P., Birks, H.J.B., and Last, W.M., (Dordrecht, Boston and London: Kluwer Academic Press), pp. 5-32.

Birks, H.J.B., and Line, J.M., 1992, The use of rarefaction analysis for estimating palynological richness from Quaternary pollen analytical data. The Holocene 2, pp. 1-10, 10.1177/ 095968369200200101.

Donque, G., 1972, The climatology of Madagascar. In Biogeography and Ecology of Madagascar, edited by Battistini, R., and Richard-Vindard, G. (Junk, The Hague), pp. 87-144.

Du Puy, D.J., and Moat, J., 1996, A refined classification of the primary vegetation of Madagascar based on the underlying geology: using GIS to map its distribution and to assess its conservation status. In Proceedings of the International Symposium on the 'Biogeography of Madagascar'+ 3 maps, edited by Lourenço W.R. (Editions de l'ORSTOM, Paris), pp. 205-218.

Gosling, W.D., Miller, C.S. and Livingstone, D.A., 2013, Atlas of the tropical West African pollen flora. Review of Palaeobotany and Palynology. 199, pp. 1-135, 10.1016/ j.revpalbo.2013.01.003. 
Grimm, E.C., 1987, CONISS: a FORTRAN 77 program for stratigraphically constrained cluster analysis by the method of incremental sum of squares. Computers and Geosciences, 13(1), pp. 13-35, 10.1016/0098-3004(87)90022-7.

Grubb, P. J., 2003, Interpreting some outstanding features of the flora and vegetation of Madagascar. Perspectives in Plant Ecology, Evolution and Systematics, 6(1-2), pp. 125-146, 10.1078/1433-8319-00046.

Hogg, A., Heaton, T., Hua, Q., Palmer, J., Turney, C., Southon, J., Bayliss, A., Blackwell, G.P., Boswijk, J., Ramsey, C.B., Pearson, C., Petchey, F., Reimer, P., Reimer, R., Wacker, L., 2020, SHCal20 Southern Hemisphere Calibration, 0-55,000 Years cal BP. Radiocarbon, 62(4), pp. 759-778, 10.1017/RDC.2020.59.

Juggins, S., 2003, C2 Version 1.5 User guide: Software for ecological and palaeoecological data analysis and visualization, (Newcastle upon Tyne: University of Newcastle).

Kershaw, A.P., 1997, A modification of the Troels-Smith system of sediment description and portrayal. Quaternary Australasia, 15(2), pp.63-68.

Moat, J. and Smith, P., 2007, Atlas de la Végétation de Madagascar, (Richmond: Royal Botanic Garden-Kew).

Razanatsoa, E., Virah-Sawmy, M., Woodborne, S., and Gillson, L., in press, Subsistence strategies and adaptation of the Mikea foragers from southwest Madagascar in the face of climate change. Malagasy Nature.

R Core Team., 2018, R: A Language and Environment for Statistical Computing R. Foundation for Statistical Computing, Vienna, https://www.R-project.org.

Stiles, D., 1998, The Mikea hunter-gatherers of southwest Madagascar: Ecology and socioeconomics. African Studies Monographs, 19, pp. 127-148.

Vallet-Coulomb, C., Gasse, F., Robison, L. and Ferry, L., 2006, Simulation of the water and isotopic balance of a closed tropical lake at a daily time step (Lake Ihotry, South-West of Madagascar). Journal of Geochemical Exploration, 88(1-3), pp. 153-156, 10.1016/j. gexplo.2005.08.103.

Vincens, A., Lézine, A.-M., Buchet, G., Lewden, D. and Le Thomas, A., 2007, African pollen database inventory of tree and shrub pollen types. Review of Palaeobotany and Palynology. 145, pp. 135-141, 10.1016/j.revpalbo.2006.09.004. 


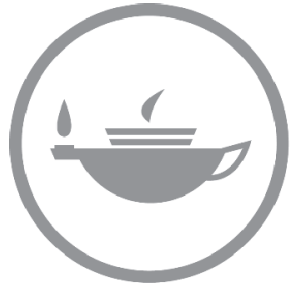

Taylor \& Francis Taylor \& Francis Group http://taylorandfrancis.com 